\title{
Rayleigh wave velocities and structural informations in Central Northern Italy *
}

\author{
P. BALDI $* *-$ M. GASPERINI ${ }^{* * *}-$ E. MANTOVANI $* * * *$
}

Received on May 15th, 1978

\begin{abstract}
Rayleigh wave dispersion has been observed along the three profiles Trieste-Olbia, Olbia-Bologna and Olbia-Bolzano, in central-northern Italy. The interpretation of phase velocities indicates a crustal thickness increasing from East $(25-30 \mathrm{~km}$, Trieste-Olbia) to West $(30-35 \mathrm{~km}$, Olbia-Bolzano). For each profile two values of the Moho depth are acceptable; the shallower one is associated with a set of models which have low velocity material $(\beta=4.3 \mathrm{~km} / \mathrm{s})$ just under or within a few $\mathrm{km}$ from the Moho; the deeper one still accepts low velocity material $(\beta=4.4 \mathrm{~km} / \mathrm{s})$ under the Moho but does not exclude the presence of an almost normal LID above the low velocity channel.
\end{abstract}

\footnotetext{
* Progetto Finalizzato Geodinamica, Pubblicazione n. 310.

$*:$ Istituto di Geolisica, Università degli Studi di Bologna.

**** Istituto Nazionale di Geofisica, Roma.

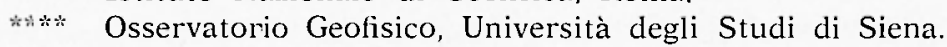




\section{RIASSUNTO}

Sono state calcolate le velocità di fase delle onde di Rayleigh per tre profili interessanti l'Italia centro-settentrionale: il Trieste-Olbia, l'OlbiaBologna e l'Olbia-Bolzano.

L'interpretazione delle curve delle velocità di fase indica un aumento dello spessore della crosta da Est a Ovest $(25-30 \mathrm{Km}$ per il profilo TriesteOlbia e $30-35 \mathrm{Km}$ per l'Olbia-Bologna). Per ogni profilo sono stati poi trovati due valori per la profondità della Moho associati ad altrettanti valori di $\beta$ nella zona a bassa velocità.

\section{INTRODUCTION}

The area covered by the three profiles studied (Fig. 1) is fairly heterogeneous; in a few hundreds of $\mathrm{Km}$ we pass from the Adriatic subplate. which has the characteristics of an aseismic continental region to the Tyrrhenian sea, traversing the Po valley, an asymetric thick sedimentary basin of the quaternary, and the Apenninic folded belt.

On the basis of (weak) seismicity some authors assume the existence of a plate boundary almost parallel to the main axis of this belt, which divides the Italian area in a western and an eastern part (Lort, 1971; McKenzie, 1972; Udias, 1975).

The western part, is represented by the Tyrrhenian slope of the Apennines and the adjacent sea; this region presents many indications of a tensional deformation which probably began in the upper Miocene and may be still active; the eastern part is mostly formed by the Adriatic plate and appears to be subjected to a compressive deformation (Elter et al., 1975); the assumption of a structural difference between the two parts is also supported by the distribution of gravity anomalies which are positive in the western part and negative in the other and by the much higher heat flow values observed on the Tyrrhenian side.

The stress field described above seems to have produced crustal thinning, probably accompanied by a rising of mantle 


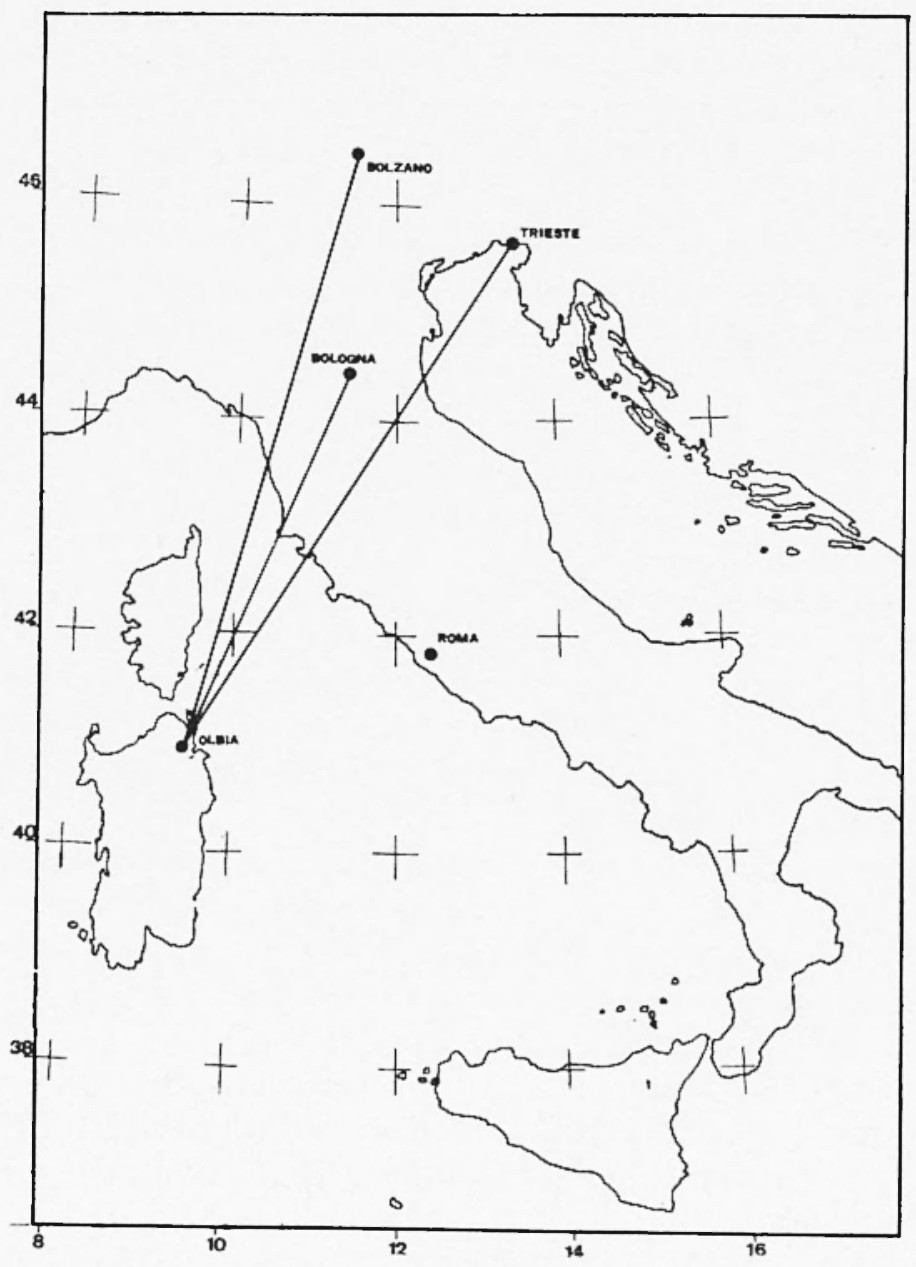

Fig. 1 - Long period seismic stations and paths along which the dispersion of Rayleigh wave has been studied. 
material on the western side and the formation of a root under the Apennines which however appears displaced with respect to the maximum elevation of the chain (Mongelli et al., 1975).

Further information on the structural features of the studied area is given by the results of the geophysical investigations reported in the literature.

In a series of earthquake studies, Caloi (1937, 1952, 1957, 1958 ) and Caloi et al. $(1956,1970)$ indicate for the Po Valley a crustal thickness of $30-34 \mathrm{~km}$ with a sedimentary cover of 3-6 $\mathrm{km}$ and a granitic layer of about $10 \mathrm{~km}$; the crust becomes thicker under thec entral Apennines $(50-55 \mathrm{~km})$ and decreases under the Ligurian sea where the granitic layer is supposed to disappear.

A list of $P_{g}, S_{g}, P_{b}, S_{b}, P_{n}$, and $S_{n}$ velocities from near event studies, relative to regions included in the area of interest, is given in Tab. I.

From seismic refraction measurements Morelli et al. (1967) and Giese - Morelli (1975) estimate a crustal thickness of 30-35 $\mathrm{km}$ in the upper Po valley and $30 \mathrm{~km}$ in the Northern Adriatic.

In the Ligurian area the crust decreases from $25 \mathrm{~km}$ from the Apennines (Giese, Morelli, 1975) to $12 \mathrm{~km}$ in the Ligurian sea (Falquist, Hersey, 1969).

Scarascia (1978) gives a crustal thickness of about $30 \mathrm{~km}$ under the Ligurian Apennines and along a profile crossing the Tyrrhenian sea between Corsica and Elba.

Using all the available gravity and seismic data, Giese Morelli (1973), give the contour map of the Moho discontinuity in Italy; by interpolation from this map it is possible roughly to estimate an average crustal thickness increasing from about 25 to $30 \mathrm{~km}$ along the profiles Trieste-Olbia, Olbia-Bologna and Olbia-Bolzano.

Mueller and Talivani (1971), by gravity data interpretation, exclude the presence of a crustal root as deep as $50 \mathrm{~km}$ under the Apennines and indicate a crustal thickness which ranges from $50-55 \mathrm{~km}$ under the eastern Alps to $25-30 \mathrm{~km}$ under the Tosco-Romagnolo Apennines.

By dispersion study of the fundamental mode Rayleigh wave, Caputo et al. (1976) give a crustal thickness of $55 \mathrm{~km}$ under the 
T A B I, E 1

\begin{tabular}{|c|c|c|c|c|c|c|}
\hline & $\begin{array}{c}V_{P E} \\
(\mathrm{Km} / \mathrm{s})\end{array}$ & $\begin{array}{c}V_{P b} \\
(\mathrm{Km} / \mathrm{s})\end{array}$ & $\begin{array}{c}V_{P n} \\
(\mathrm{Km} / \mathrm{s})\end{array}$ & $\begin{array}{c}V_{s_{g}} \\
(\mathrm{Km} / \mathrm{s})\end{array}$ & $\begin{array}{c}V_{s b} \\
(\mathrm{Km} / \mathrm{s})\end{array}$ & $\begin{array}{c}V_{s \eta} \\
(\mathrm{Km} / \mathrm{s})\end{array}$ \\
\hline $\begin{array}{c}\text { Veneto Region } \\
\text { (1) }\end{array}$ & $5.7 \pm 0.04$ & $6.61 \pm 0.04$ & $8.0 \pm 0.04$ & $3.36 \pm 0.03$ & 3.64 & $4.41 \pm 0.02$ \\
\hline $\begin{array}{c}\text { Upper Adriatic } \\
\text { (1) }\end{array}$ & - & - & $7.77+0.08$ & - & - & $4.8 \pm 0.01$ \\
\hline $\begin{array}{r}\text { Po Valley } \\
(1)\end{array}$ & 5.1 & $\begin{array}{l}6.1 \\
6.9\end{array}$ & - & 3.08 & - & - \\
\hline $\begin{array}{l}\text { Toscany } \\
\text { (1) }\end{array}$ & $\begin{array}{l}5.2-5.4 \\
5.25\end{array}$ & $\begin{array}{c}- \\
6.63 \pm 0.08\end{array}$ & $\begin{array}{l}7.86 \pm 0.04 \\
8.16 \pm 0.06\end{array}$ & $\begin{array}{l}3.01 \pm 0.04 \\
3.06 \pm 0.1\end{array}$ & $\begin{array}{c}- \\
3.57+0.04\end{array}$ & $\begin{array}{l}4.34 \pm 0.02 \\
4.44 \pm 0.02\end{array}$ \\
\hline $\begin{array}{c}\text { Central Italy } \\
\text { (2) }\end{array}$ & 5.6 & - & 7.9 & $3.2-$ & - & 4.35 \\
\hline $\begin{array}{l}\text { Liguria } \\
\qquad(3)\end{array}$ & $5.7-5.9$ & $6.7-7.0$ & 7.6 & $3.3-3.5$ & $3.6-3.9$ & $4.0-4.4$ \\
\hline
\end{tabular}

TABLE 1 - Crustal and submoho velocities observed in Central Northern Italy by: (1) Caloi, 1952; (2) Console \& Gasparini, 1975; (3) Bossolasco et al., 1972. 
Apennines, but undoubtedly this large value is connected with the high velocity and the simplified model assumed for the crust in the inversion of the dispersion curves.

Nolet - Panza - Wortel (1977), here too with surface wave, study, indicate an average crustal thickness of $35 \mathrm{~km}$ for the Adriatic plate and Central-Northern Apennines; they report also evidence, by the study of group velocity dispersion of surface waves from near events, against strong shallow lateral heterogeneity between the Adriatic sea and the Apennines.

EXPERIMENTAL RESULTS

The information on the events selected for this study are set out in Table II and the profiles studied are shown in Fig. 1.

The long period stations are equipped with standard seismographs (15-100 WWSSN equivalent). The record were digitized at 2-seconds intervals and analysed with the frequency-filtering and time windowing tecniques described by Knopoff - Muller - Pilant (1966), Biswas - Knopoff (1974), and Panza (1976).

The phase velocities obtained for the three profiles (Fig. 2) appear very similar for periods longer than about $40 \mathrm{sec}$, while show an appreciable separation for shorter periods indicating that the lateral heterogeneity of the structure, under the three profiles, is mainly confined to a region not much deeper than the Moho.

INVERSION

For inversion we selected eight points from each dispersion curve.

The spherical-Earth Rayleigh-wave phase-velocity values were reduced to flat-Earth values by the empirical correction of Bolt - Dorman (1961), for a direct comparison with the dispersion results of the faster flat-Earth computer program. 
T A B L E I I

\begin{tabular}{|c|c|c|c|c|c|c|c|}
\hline & $\begin{array}{l}\text { Date and time } \\
\text { (GMT) }\end{array}$ & Location & $\begin{array}{l}\text { Depth } \\
\text { Km }\end{array}$ & Magnitude & $\begin{array}{l}\text { Distance to } \\
\text { first station } \\
\mathrm{Km}\end{array}$ & $\begin{array}{c}\text { Station } \\
\text { used }\end{array}$ & $\begin{array}{l}\text { Deviation } \\
\text { to the great } \\
\text { circle }\end{array}$ \\
\hline 1 & $\begin{array}{l}\text { March, } 31,1972 \\
153653.5\end{array}$ & $\begin{array}{l}\text { Sandwich Islands } \\
55.3 \mathrm{~S}, 29.1 \mathrm{~W}\end{array}$ & $\mathbf{N}$ & 5.9 & 11250 & OLB-BLZ & $7^{\circ}$ \\
\hline 2 & $\begin{array}{l}\text { March, } 251972 \\
225940.3\end{array}$ & $\begin{array}{l}\text { Kurily Islands } \\
43.4 \mathrm{~N}, 146.0 \mathrm{E}\end{array}$ & 43 & 6.0 & 9000 & TRI-OLB & $1.8^{\circ}$ \\
\hline 3 & $\begin{array}{l}\text { June, } 24,1974 \\
203435.4\end{array}$ & $\begin{array}{l}\text { Sandwich Islands } \\
55.8 \mathrm{~S}, 27.5 \mathrm{~W}\end{array}$ & 80 & 6.0 & 12250 & OLB-BOL & $0.1^{\circ}$ \\
\hline
\end{tabular}

TABLE 2 - List of events studied. 
The inversion of the data was effected by the non-linear approach (Hedgehog) with a search in a multidimensional parameter-space (crustal, lid and channel thickness, lid and channel velocities) for the models satisfying the observations with a given uncertainty.

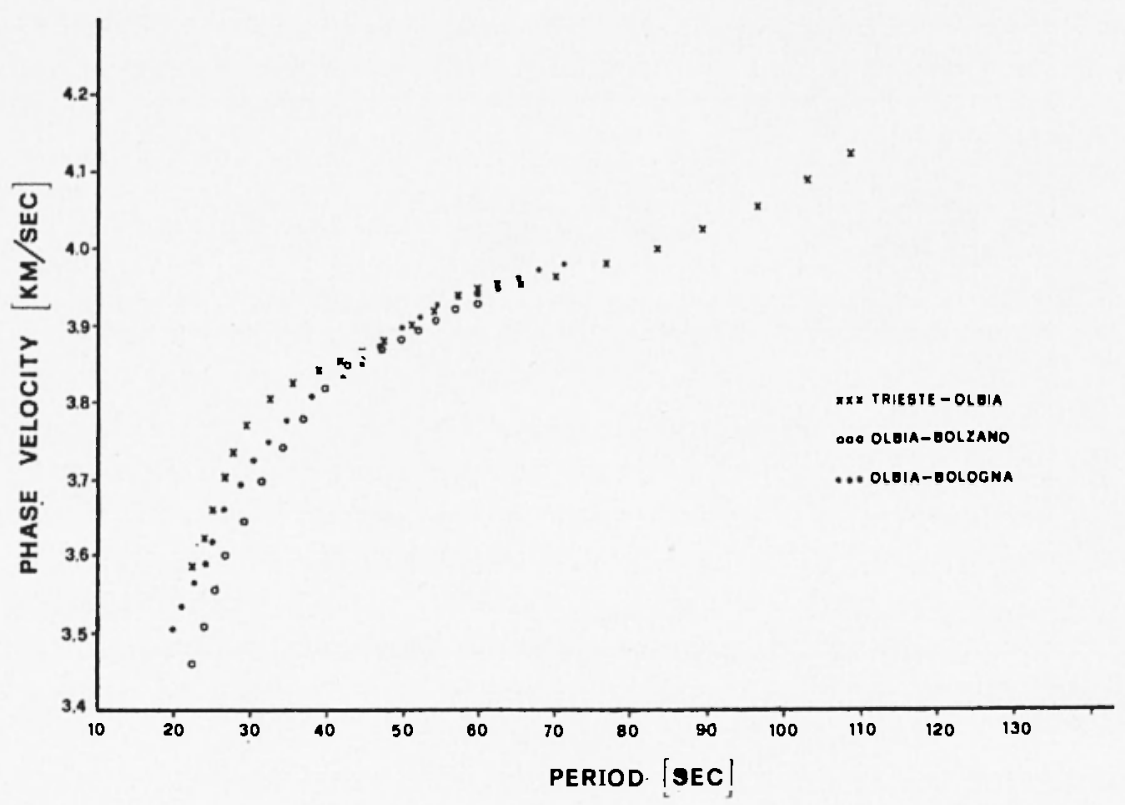

Fig. 2 - Rayleigh wave phase velocities measured along the profiles shown in Fig. 1.

The layering of the structure and the range of the parameter values used in the inversion, are shown in Tab. III.

For the crust we adopted a two-layered model with a sedimentary cover at the top. During inversion the thickness of unconsolidated sediments, tentatively assessed at $3 \mathrm{~km}$ from geological information, has been kept fixed; the variations of the crustal thickness were absorbed, in an equal proportion, by the 
other two crustal layers. The range of variation for the other parameters used in the search, was chosen taking in account the available information on the area and the results of earlier surface wave studies. (Knopoff et al., 1966; Berry - Knopoff, 1967; Nolet et al., 1977; Calcagnile, Panza e Knopoff, 1977).

A point in the 5-dimensional space is accepted if the theoretical-experimental phase velocity difference for each period is less than $0.05 \mathrm{~km} / \mathrm{s}$ and the root mean-square of all eight differences is less than $0.03 \mathrm{~km} / \mathrm{s}$. These estimates of error are based on spacing between the stations, the presence of disturbances in the records, like those due to multipathing and the good accordance with phase velocities obtained by Nolet et al. (1977) for the same area.

The results of the inversion for the three profiles are plotted, in a four dimensional representation, in fig. 3,4 and 5.

\section{INTERPRETATION}

\section{Trieste-Olbia}

For this profile only the values of 25 and $30 \mathrm{~km}$ are accepted as crustal thickness $\left(H_{1}\right)$; let us consider these two sets of models separately: $H_{1}=25 \mathrm{~km}$ : the material directly under the Moho presents in most cases a very low velocity $\left(\beta_{2}=4.3 \mathrm{~km} / \mathrm{s}\right)$; the few cases with higher velocities are always related to very thin layers.

This low velocity zone, including also the underlying channel, extends from about the Moho downward and presents a minimum thickness of $70 \mathrm{~km}$; its bottom is not determined by the available data.

$H_{1}=30 \mathrm{~km}$ : for this crustal thickness, material with a velocity fairly low $\left(\beta_{2}=4.4 \mathrm{~km} / \mathrm{s}\right)$ may still exist directly under the Moho, but solutions with an almost normal LID $\left(\beta_{2}=4.4 \div 4.5\right.$ $\mathrm{km} / \mathrm{s}$ ) which may extend as deep as $70 \mathrm{~km}$ under the Moho, are also taken into account (Fig. 3). 
T A B L E I I I

\begin{tabular}{|c|c|c|c|c|}
\hline & $\begin{array}{l}\text { Thickness } \\
H(\mathrm{Km})\end{array}$ & $\begin{array}{l}\text { Density } \\
\left(\mathrm{g} / \mathrm{cm}^{3}\right)\end{array}$ & $\begin{array}{c}P \text {-wave velocitty } \\
(\mathrm{Km} / \mathrm{s})\end{array}$ & $\begin{array}{c}S \text {-wave velocity } \\
(\mathrm{Km} / \mathrm{s})\end{array}$ \\
\hline SEDIMENT & 3 & 2.25 & 3.4 & 2.0 \\
\hline CRUST 1 & $20 \leq H_{1} \leq 45$ & 2.65 & 5.7 & 3.2 \\
\hline CRUST 2 & $\Delta H_{1}=5$ & 2.90 & 6.6 & 3.65 \\
\hline LID & $\begin{array}{r}10 \leq H_{2} \leq 80 \\
\Delta H_{2}=10\end{array}$ & 3.43 & 8 & $\begin{array}{c}4.30<\beta_{2}<4.50 \\
\Delta \beta_{2}=0.1\end{array}$ \\
\hline $\begin{array}{l}\text { LOW VELO- } \\
\text { CITY CHANNEL }\end{array}$ & $\begin{array}{c}30<H_{3}<130 \\
\Delta H_{3}=20\end{array}$ & 3.45 & 7.8 & $\begin{array}{c}4.10<\beta_{3}<4.30 \\
\Delta \beta_{3}=0.1\end{array}$ \\
\hline SUB CHANNEL 1 & $H_{4}=295-\Sigma H_{\mathrm{i}}$ & 3.5 & 8.3 & 4.52 \\
\hline SUB CHANNEL 2 & 106 & 3.55 & 8.5 & 4.66 \\
\hline HALF SPACE & $\infty$ & 3.75 & 9.10 & 5.0 \\
\hline
\end{tabular}

TABlE 3 - Scheme of structural mode adopted for the thickness of the sediments has been kept fixed during inversion; the variations in crustal thickness were absorbed, in a equal proportion, by the other two crustal layers. 


\section{Olbia-Bologna}

The accepted crustal thicknesses are 25 and $30 \mathrm{~km}$.

$H_{1}=25 \mathrm{~km}$ : the number of these solutions is rather low and all of them are associated with low velocity material $\left(\beta_{2}=4.3 \div-4.4\right.$ $\mathrm{km} / \mathrm{s}$ ) directly under or within $10 \mathrm{~km}$ from the Moho; the velocity undergoes a further decrease in the underlying channel $\left(\beta_{3}=\right.$

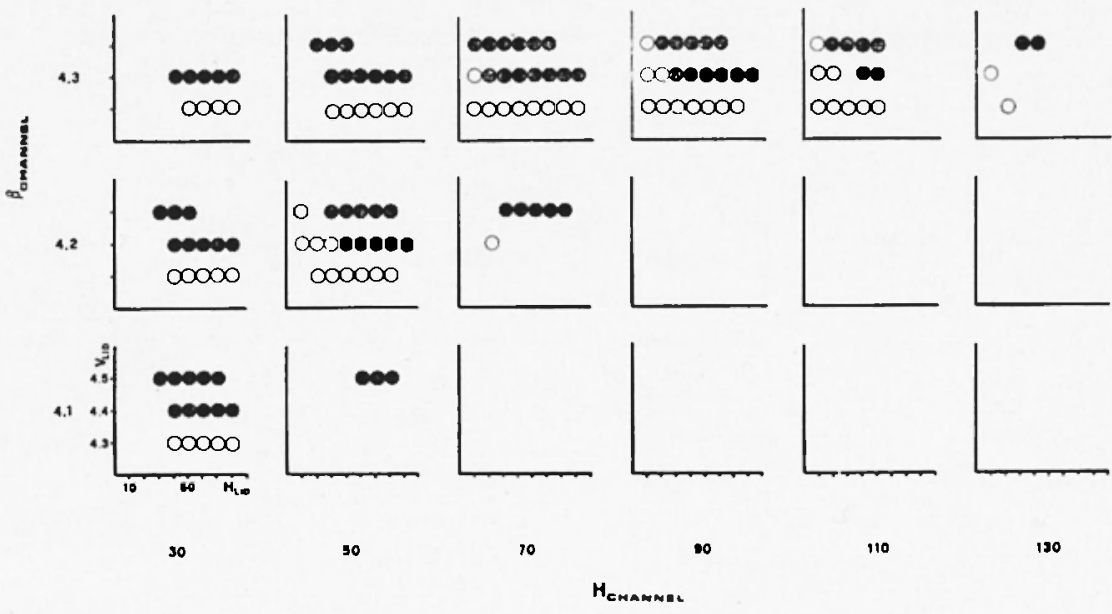

Fig. 3 - Representation in a four dimensional parameter space of the successful solutions from the inversion of phase velocities for the profile TRI-OLB. Empty and full circles indicate crustal thickness respectively of 25 and $30 \mathrm{Km}$; in no cases were both values accepted contemporaneously.

4.1-4.2 $\mathrm{km} / \mathrm{s}$ ). In all cases the entire low velocity zone has a maximum thickness of $80 \mathrm{~km}$.

$H_{1}=30 \mathrm{~km}$; with this crustal thickness, low velocity material $\left(\beta_{2}=4.3 \mathrm{~km} / \mathrm{s}\right)$ just under the Moho is still accepted, but alternative solutions with LID of $4.5 \mathrm{~km} / \mathrm{s}$ as thick as $40 \mathrm{~km}$ are also taken into account (Fig. 4). 


\section{Olbia-Bolzano}

The crustal thickness can be of 30 and $35 \mathrm{~km}$.

$H_{1}=30 \mathrm{~km}$ : low velocity material $\left(\beta_{2}=4.3 \mathrm{~km} / \mathrm{s}\right)$ is accepted under or within $10 \mathrm{~km}$ from the Moho; this zone may extend down to a depth of $100 \mathrm{~km}$ with a velocity in the lower part of

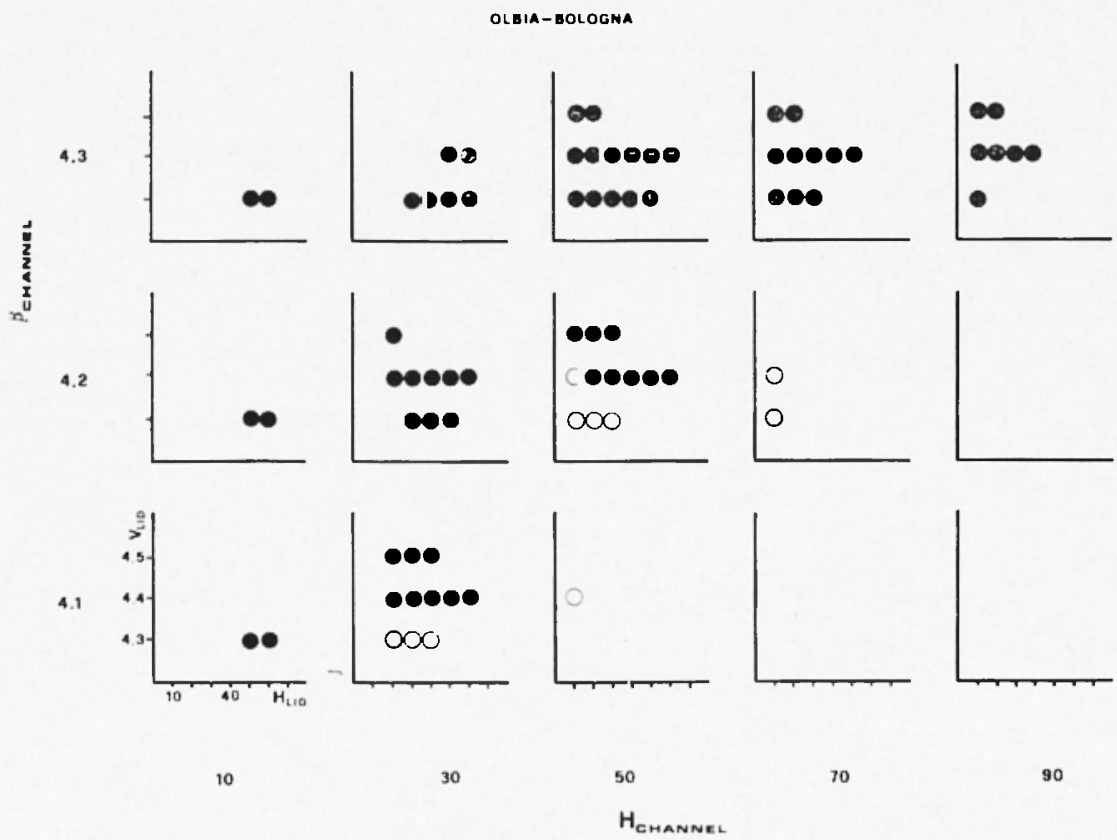

Fig. 4 - Results of the inversion for the profile OlbiaBologna. Emply circles $\left(H_{\mathrm{CrUST}}=25 \mathrm{Km}\right)$, full circles $\left(H_{\text {CRUST }}=30 \mathrm{Km}\right)$.

4.1-4.2 km/s. The resolution of the velocity in the first $10 \mathrm{~km}$ under the Moho is very poor.

$H_{1}=35 \mathrm{~km}$ : in this case the material under the Moho never presents a velocity as low as $4.3 \mathrm{~km} / \mathrm{s}$, but a value of $4.4 \mathrm{~km} / \mathrm{s}$, still low for the LID, is largerly accepted; solutions with LID velocity of $4.5 \mathrm{~km}$ as thick as $50 \mathrm{~km}$ are not excluded (Fig. 5). 
For the channel the lack of phase velocity information at long periods and the intrinsic ambiguity due to the mutual compensation of layer thickness and velocity variations, allows a poor resolution on these single parameters.

The analysis of the three profiles, considered together suggests a subdivision of all the models in two main types: one showing low velocity material just under or very near to the

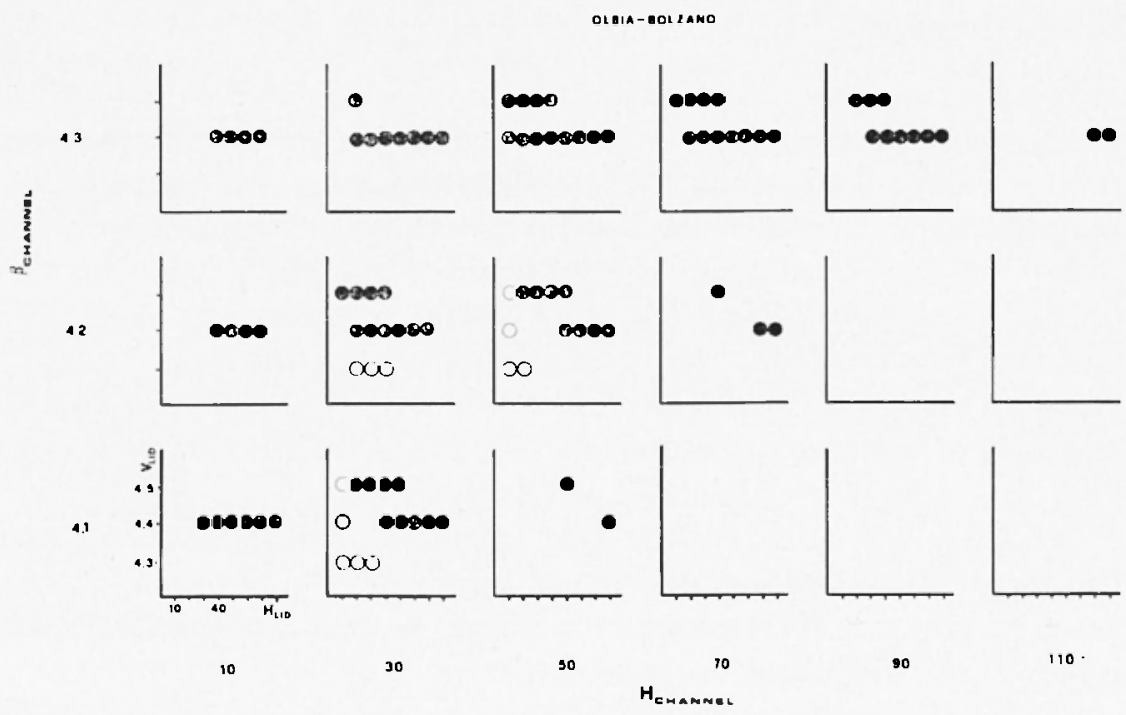

Fig. 5 - Results of the inversion for the profile OlbiaBolzano. Emply circles $\left(H_{\text {Crust }}=30 \mathrm{Km}\right)$, full circles $\left(H_{\text {CRUST }}=35 \mathrm{Km}\right)$.

Moho and a second which do not exclude a LID with almost nortmal velocity and thickness; it is possible to express some preference for the first structural type, considering that large portions of the profile studied lay on the western side of the Apennines and on the Tyrrhenian sea where the supposed tensional stress field could have produced a rising of hot mantle material.

Other evidence supporting the above preference is represented by strong positive heat flow anomalies along the circum- 
tyrrhenian region (Mongelli, Loddo, 1974) and by the low $P_{n}$ and $S_{\mathrm{n}}$ velocities observed in the area (see Table I). Further, the crustal thicknesses associated with this kind of model, ranging from $25 \mathrm{~km}$ along TRI-OLB to $30 \mathrm{~km}$ along OLB-BLZ, seem in good agreement with the values indicated by other geophysical investigations.

\section{CONCLUSIONS}

The interpretation of surface wave dispersion curves in Central Northern Italy indicates a thicknening of the crust from the direction Trieste-Olbia to Bolzano-Olbia. For each profile two main structrual types are recognizable in the set of the acceptable solutions: one with low velocity material just under or within a few $\mathrm{km}$ from the Moho and an other which do not exclude an almost normal LID to a low velocity channel. The crustal thickness along the three profiles ranges from 25 to $30 \mathrm{~km}$ in the first case and from 30 to $35 \mathrm{~km}$ in the second.

A preference for the first type of model can be expressed on the basis of earlier geophysical observations in the area which seem to support the assumption of the presence of low velocity material not far from the Moho.

\section{AKNOWLEDGEMENTS}

We are grateful to Dr. Guust Nolet for critically reading the manuscript and for useful suggestions. This work has been financially supported by the Italian Research Council (CNR) Progetto Finalizzato Geodinamica under contract n. 310. 


\section{REFERENCES}

BERRY M. J., KNOPOFF L., 1967 - Structure of the upper mantle under the Western Mediterranean Basin. "J. Geophys. Res.", 72, p. 3613.

Biswas, N. N., KNOPOFF L., 1974 - Structure of the upper mantle under the United States from the dispersion of Rayleigh waves. "Geophys. B4J. Roy. Astron. Soc.", 36, p. 515.

Bolt B. A. Dormann J., 1961 - Phase and group velocitie of Ravleigh waves in a spherical, gravitating earth. "J. Geophys. Res.", 66, p. 2965.

Bossolasco M., Cicconi G., Eva C. Pasouale V., 1972 - La rete sismica dell'Istituto geofisico di Genova e primi risultati sulla sismo-tettonica delle Alpi Marittime e del Mar Ligure. "Rivista It. di Geofisica ", 5, n. 229.

Calcagnile G., Panza G. F., KNopoff L., 1977 - Upper mantle structure of North-Central Italy from Rayleigh waves phase velocities. (Abstract) Proceedings of the IASPEI/IAVCEI Meeting. Durham.

CALoI P., 1937 - Il terremoto adriatico del 30 novembre 1934. « Boll. Soc. Siismol. Ital. ", XXXV.

Calor P., 1951 - Struttura geologica-sismica dell'Europa centro-meridionale dell'Italia e del Mediterraneo centro-occidentale, quale risulta da recenti ricerche compiute in Italia. Presentato al Convegno della "Commission Seismologique Europeenne", Stoccarda.

Calor P., De Panfilis M., di Filippo D., Marcelli L., Spadea M. C., 1956 . Terremoti della Val Padana del 15-16 maggio 1951. "Annali di Geofisica", IX, 1.

Calor P., 1957 - Caratteristiche della crosta terrestre dalle Alpi agli Ap. pennini. "Annali di Geofisica ", X, 3.

CALOI P., 1958 - La crosta terrestre dagli Appennini all'Atlantico, ricostruita sulla base dei rilievi sismici. "Ann. di Geofisica ", XI, 1, p .250.

Caloi P., Romuldoi G., Spadea M.C., 1970 - Caratteristiche sismiche $e$ geodinamiche della Val Padana quali risultano dall'attività sismica ivi verificatasi, dall'inizio dell'Era Volgare a tutto il 1969. "Annali di Geofisica ", XXIII, 2-3, p. 59.

Caputo M., Knopoff L., Mantovani E., Muel.ler S., Panza G. F., 1976 Rayleigh wave phase velocities and upper mantle structure in the Apennines. "Annali di Geofisica", XXVIIII, 4, 2.

Console R., Gasparini C., 1975 - Some notes on the velocity of seismicwaves in Central Italy. "Annali di Geofisica ", XXVIII, 1, p. 65. 
Eltrer P., Biglin G., Tongiorgi M., Trevisan L., 1975 - Tensional and compressional areas in the recent (Tortonian to present) evolution of the northern Apennines. "Boll. Geof. Teor., Applic.", 65, 3.

Fanlouist D. A., Hersey J. B., 1969 - Seismic refraction measurements in the western Mediterranean Sea. "Bull. Inst. Oceanogr.", Monaco, 67. p. 1386.

Gilse P., Morelli C., 1973 - Structural map of Moho. In "Structural model of Italy ", Sheet South 2, CNR, Rome.

Giese P., Morelu. C., 1975 - Crustal structure in Italy. In "Structural Model of Italy", "Quaderni de La Ricerca Scientifica ", CNR.

Knoporf L., St. Mueldi:R, Pilant W. L., 1966 - Structure of the crust and upper mantle in the Alps from the phase velocity of Ravleigh waves. "Bull. Seism. Soc. Am.", 56, 1009.

KNOPOFF L., 1972 - Observation and inversion of surface wave dispersion. "Tectonophysics", 13, p. 497.

LORR J. M., 1971 - The tectonics of the Eastern Mediterranean, a geophysical review. "Rev. Geophys ", 9, p. 189.

McKenzie D., 1972 - Active Tectonics of the Mediterranean Region "Geophys. J. R. Astr. Soc. », 30, p. 109.

Mongell. F., LomDo M., 1974 - The present state of Geothermal investigation in Italy. "Acta Geodaet. Geophys, et Montainist " Acad. Sc. Hung., 9, p. 449.

Mongelli F., Lomo M., Calchgnil: G., 1975 - Some observations on the Apennines gravity field. "Earth and Planetary Sc. Letters", 24, j. 385.

Morelli C., Bellemo S., Finetti I., de Visentini G., 1967 - Preliminary depth contour maps for the Conrad and Moho discontinutities in Ettrope. "Boll. di Geof. Teorica e Applicata", 34, p. 142.

Murlle: S., Thlwani M., 1971 - A crustal section across the eastern Alps based on gravity and seismic refraction data. "Pageoph", 85, p. 226.

Noli:t G., Panza G. F., Wortel R., 1978 - An average model for the Adriatic subplate. "Pageoph".

Panza G. F., 1976 - Phase velocity determination of fundamental and Rayleigh waves. "Pageoph. ", V, 114, p. 747.

SCARAscin P., 1978 - Crustal and upper mantle structure in the Liguria Sea and adjacent area. "Boll. Geof. Teor. Applicata".

Udus A., 1975 - Seismicity and possible plate botndary relations in the Western Mediterranean. In H. Stiller (ed.), Proc. of the XIVth General Assembly of the ESC (Trieste, 1974), Berlin, p. 395. 